\title{
EMPIRICAL RESEARCH OF INFLUENCING STUDENTS'ATTITUDES TOWARDS TEACHING SUBJECTS BY MULTIMEDIA TEACHING MATERIALS
}

\author{
Ján ZÁHOREC - Alena HAŠKOVÁ
}

\begin{abstract}
The contribution follows the authors' article published in the previous JTIE issue (Záhorec - Hašková, JTIE, 1/2009, s. 83 - 91). Following the empirically derived hierarchy of subjects identifying degrees of particular teaching subjects popularity among grammar school students, and influence of various factors on students' attitude toward these subjects the authors explored possibilities to eliminate students' negative attitudes and approaches to so-called unfavourite ones, which just natural science and technical disciplines belong to. In the concrete they focused on physics, which was identified as the least favourite subject. In this paper the authors present results of a pedagogical experiment which aim was to verify positive influence of multimedia teaching materials educational intervention on students' negative approach to physics.
\end{abstract}

Key words: students' negative attitude towards subjects, elimination of negative attitudes, educational intervention of multimedia teaching aids, physics, interactive flash-animations, Kruskal-Wallis ANOVA, Median Test.

\section{EMPIRICKÝ VÝSKUM OVPLYVŇOVANIA VZŤAHU ŠTUDENTOV K VYUČOVACÍM PREDMETOM PROSTREDNÍCTVOM MULTIMEDIÁLNYCH UČEBNÝCH MATERIÁLOV}

\begin{abstract}
Abstrakt: Príspevok nadväzuje na článok uverejnený v predchádzajúcom čísle časopisu (ZáhorecHašková, JTIE, 1/2009, s. 83 - 91). V nadväznosti na empiricky odvodenú hierarchiu predmetov identifikujúcu mieru oblúbenosti jednotlivých vyučovacích predmetov medzi študentmi gymnazistami a vplyv rôznych faktorov na ich postoje k predmetom autori prostrednictvom pedagogického experimentu skúmali možnosti eliminácie negatívnych postojov študentov $k$ tzv. neoblúbeným predmetom, ku ktorým sa vo všeobecnosti radia práve prírodovedné a technické discipliny. Konkrétne sa zamerali na fyziku identifikovanú ako najmenej oblúbený predmet. $V$ tomto článku prezentujú výsledky pedagogického experimentu, ktorého ciel'om bolo overit' predpokladaný pozitívny vplyv pedagogickej intervencie multimediálnych učebných materiálov na negativne postoje študentov $k$ fyzike.
\end{abstract}

Kl'účové slová: negatívny vzt'ah študentov $k$ vyučovacím predmetom, eliminácia negatívnych vzt'ahov, pedagogická intervencia multimediálnych učebných pomôcok, fyzika, interaktívne flashanimácie, Kruskal-Wallisov test, mediánový test.

1 Úvod

Ako sme dokumentovali v príspevku uverejnenom v predchádzajúcom čísle časopisu (Záhorec - Hašková, JTIE, 1/2009), informatika a programovanie nepatria do kategórie vyučovacích predmetov, ku ktorým by študenti mali výrazne negatívny vzt'ah. $\mathrm{Na}$ druhej strane však bol potvrdený všeobecný negatívny vzt'ah študentov k prírodovedným predmetom chémia a fyzika; pritom fyziku spolu s matematikou môžeme pokladat' za základ technických disciplín. Okrem prezentovaných zistení sme naznačili možnost', že náležité využívanie multimediálnych učebných materiálov by nemuselo mat' dopad len na zvyšovanie efektívnosti vyučovania ale mohlo by prispievat' aj $\mathrm{k}$ eliminácii negatívnych postojov študentov k prírodovedným a technickým disciplínam. Tento predpoklad sme dávali do súvisu hlavne s popularitou, ktorú majú u mládeže moderné technické prostriedky, ale aj $\mathrm{s}$ výsledkami výskumu vplyvu informačných technológií a informačných kompetencií učitel'ov na postoje žiakov k vlastnému procesu učenia (Nagy - Kubiatko - Nagyová, 2008). Náš predpoklad, že pedagogickou intervenciou multimediálnych učebných materiálov je možné znižovat' mieru neoblúbenosti vyučovacích predmetov, sme overovali na vyučovacom 
predmete fyzika, ktorý bol identifikovaný ako najneoblúbenejší predmet (Záhorec - Hašková, JTIE, 1/2009).

\section{Zameranie výskumu a metodika pedagogického experimentu}

Hlavným ciel’om nami realizovaného výskumu bolo, ako sme naznačili, overenie možností využívania multimédiami podporovaného vyučovania na elimináciu vysokej miery neoblúbenosti určitých predmetov, pričom sme sa sústredili na fyziku ako výrazne neoblúbený predmet (Záhorec, 2008). Vzhl'adom na vytýčený ciel' sme posudzovali možnosti monitorovat' a vedecky podložit' identifikáciu prípadných navodených pozitívnych zmien vo vzt'ahoch a postojoch študentov k sledovanému predmetu. $\mathrm{Na}$ overenie stanovenej hypotézy nášho výskumu, $\mathrm{v}$ ktorej predpokladáme, že vyučovanie podporované elektronickými výučbovými prostriedkami prispieva $k$ znižovaniu negativnych postojov $k$ vyučovacím predmetom, konkrétne $k$ vyučovaciemu predmetu fyzika, sme sa rozhodli použit' pedagogický experiment. Výskum prebiehal v nasledujúcich fázach:

- Príprava experimentálnych učebných materiálov. Konštrukcia dotazníkov experimentu.

- Posúdenie kvality vyvíjaných výskumných nástrojov (interview $\mathrm{s}$ jednotlivcami v pilotnej štúdii pre overenie vyvíjaných výskumných nástrojov, analýza spol’ahlivosti/položiek dotazníka).

- Vytvorenie kontrolnej a experimentálnej skupiny.

- Administrovanie dotazníkov.

- Realizácia experimentálneho plánu.

- Readministrovanie dotazníkov. Evaluácia vytvorených e-produktov.

- Porozumenie dátam.

- Overenie validity použitých štatistických metód.

- Analýza dát.

- Interpretácia výsledkov výskumu.

Experimentálne učebné materiály sme zamerali na oblast' geometrickej optiky. Viedla nás $\mathrm{k}$ tomu skutočnost', že táto čast' fyziky je súčast'ou kurikúl všetkých typov stredných škôl, pričom jej spracovanie $\mathrm{v}$ učebniciach fyziky nebýva pre študentov príliš prít’ažlivé kvôli značnej abstraktnosti základných pojmov nutných $\mathrm{k}$ pochopeniu preberanej problematiky. Abstraktnost' pojmov a javov spadajúcich do oblasti geometrickej optiky je však možné výrazne znížit' využitím interaktívnych animácií, ktoré prispievajú knázornosti a pochopeniu jednotlivých fenoménov a ich dynamiky. Pri vývoji experimentálnych učebných materiálov sme sa snažili vyvarovat' akéhokol'vek náznaku encyklopedického hromadenia informácií a hlavný akcent sme položili na názorné predvádzanie preberaných javov prostredníctvom interaktívnych animácií. V konečnom dôsledku bol vytvorený multimediálny program Základy geometrickej optiky, ktorý obsahovo korešponduje s učebnými osnovami tematického celku Svetlo a žiarenie fyziky 4. ročníka gymnázia (resp. 8. ročníka gymnázia s osemročným štúdiom). Základné učivo je spracované v 16 flashprezentáciách ( $\mathrm{v}$ prostredí aplikácie Adobe Flash 8 - bývalá Macromedia Flash) a 60 flashanimáciách určených pre názorné vysvetlenie a lepšie pochopenie preberaných fyzikálnych pojmov a javov. Doplňujúcim učebným materiálom sú plne interaktívne fyzlety umožňujúce interaktívnu simuláciu fyzikálnych dejov s aktívnym prístupom študentov. Vývoj elektronických učebných materiálov bol prvým, no logicky najdôležitejším krokom k dosiahnutiu vytýčeného ciel'a výskumného pôsobenia. Všetky učebné materiály vyvinuté špeciálne pre potreby nášho výskumu sú však použitel'né pre podporu vyučovania aj bez špeciálneho zamerania účelu ich využitia vo výchovno - vzdelávacom procese.

Pedagogický experiment sme realizovali v období rokov 2007 - 2008 na Gymnáziu Golianova ul. v Nitre. Výskumnú vzorku tvorili študenti 4. ročníka štvorročnej vetvy tohto gymnázia a 8. ročníka (oktáva) jeho osemročnej vetvy (t.j. študenti vekovej úrovne $17-19$ rokov). Výber subjektov do experimentálnej a kontrolnej skupiny bol podriadený študijným plánom a rozvrhom. Pedagogická intervencia nami vyvinutých elektronických učebných materiálov Základy geometrickej optiky a interaktívnej elektronickej učebnej pomôcky v podobe animovaných (flash) prezentácií do vyučovacieho procesu bola realizovaná jednak počas klasických vyučovacích hodín a jednak počas seminárov $\mathrm{z}$ fyziky. Obsahovo organizačné zabezpečenie pedagogického experimentu je prezentované $\mathrm{v}$ tabul'ke 1. Experimentálnu skupinu A (ESA) tvorili študenti 8. ročníka osemročného gymnázia so zameraním na informatiku a programovanie a na multimediálnu podporu vzdelávacej 
činnosti $\mathrm{v}$ tejto skupine boli použité nami vytvorené učebné materiály. Experimentálnu skupinu B (ESB) tvorili študenti 8. ročníka osemročného gymnázia so zameraním na cudzie jazyky a na multimediálnu podporu vzdelávacej činnosti v tejto skupine sme použili elektronické učebné materiály Výukové prezentácie pre podporu vyučovania fyziky (autor: Jozef Beňuška, CD). Kontrolnú skupinu (KS) tvorili študenti 4. ročníka štvorročného gymnázia so zameraním na informatiku. V ich prípade výučba prebiehala štandardným spôsobom v bežnej učebni pomocou klasickej učebnice bez využitia vyššie uvádzaných experimentálnych materiálov.

Z hladiska vedomostnej úrovne jednotlivé skupiny neboli rovnocenné ale $\mathrm{v}$ našom prípade táto rozdielnost' nebola v rozpore s korektnost'ou, nakol'ko sme sledovali možnosti ovplyvňovania vzt’ahu študentov $\mathrm{k}$ fyzike prostredníctvom pedagogickej intervencie nami vyvinutých materiálov do vyučovacieho procesu a nie zvyšovanie efektivity vzdelávania.

Skladba jednotlivých skupín zaradených do pedagogického experimentu je uvedená $\mathrm{v}$ tabul'ke 2.

\begin{tabular}{|c|c|c|c|}
\hline $\begin{array}{c}\text { Skupiny } \\
\text { pedagogického } \\
\text { experimentu }\end{array}$ & Pretest & $\begin{array}{c}\text { Spôsob pedagogickej } \\
\text { intervencie }\end{array}$ & Posttest \\
\hline ESA & D1, D2 & VMPV, MUMZGO & D1, DŠ \\
\hline ESB & D1, D2 & VMPV, MCD & D1 \\
\hline KS & D1, D2 & KKV, KTU & D1 \\
\hline
\end{tabular}

Tabul'ka 1: Plán pedagogického experimentu.

Legenda $\mathrm{k}$ tabul'ke:

$\mathrm{KS}=$ kontrolná skupina, ESA = experimentálna skupina $\mathrm{A}, \mathrm{ESB}=$ experimentálna skupina $\mathrm{B}$, $\mathrm{KKV}=$ klasická kontaktná výučba, VMPV = vizuálna multimediálna podpora vzdelávania, $\mathrm{KTU}=$ klasická textová učebnica, MUMZGO = multimediálny učebný materiál Základy geometrickej optiky, $\mathrm{MCD}=$ multimediálny vzdelávací titul Výukové prezentácie pre podporu vyučovania fyziky na $\mathrm{CD}, \mathrm{D} 1$ vstupný dotazník D1, D2 - vstupný dotazník D2, DŠ - dotazník Štúdium fyziky pomocou e-produktov Základy geometrickej optiky.

\begin{tabular}{|c|c|c|c|c|}
\hline Skupina & $\begin{array}{c}\text { Experimentálna A } \\
\text { (ESA) }\end{array}$ & $\begin{array}{c}\text { Experimentálna B } \\
\text { (ESB) }\end{array}$ & Kontrolná (KS) & \\
\hline Ročník & $\begin{array}{l}\text { 8. (osemročné } \\
\text { štúdium) OKB }\end{array}$ & $\begin{array}{l}\text { 8. (osemročné } \\
\text { śtúdium) OKA }\end{array}$ & $\begin{array}{l}\text { 4. (štvorročné } \\
\text { śtúdium) 4.C }\end{array}$ & Spolu \\
\hline chlapcov & 18 & 6 & 18 & 42 \\
\hline dievčat & 8 & 18 & 5 & 31 \\
\hline Spolu & $\mathbf{2 6}$ & $\mathbf{2 4}$ & $\mathbf{2 3}$ & $\mathbf{7 3}$ \\
\hline
\end{tabular}

Tabul'ka 2: Skladba experimentálnej a kontrolnej skupiny v rámci pedagogického experimentu.

$\mathrm{Na}$ diagnostikovanie navodených zmien vzt’ahu študentov k sledovanému predmetu sme zostavili dotazník Zistovanie vztahu a postojov študentov k vyučovaciemu predmetu fyzika (D1), ktorý bol administrovaný ako pretest pred a ako posttest po pedagogickom experimente. Dotazník D2 bol zameraný na určovanie miery oblúbenosti vyučovacích predmetov (vid' príspevok v predchádzajúcom čísle).

\section{Výsledky pedagogického experimentu} a ich interpretácia

$\mathrm{Z}$ údajov získaných administrovaním vytvoreného dotazníka D1 pred (pretest) a po (posttest) pedagogickom experimente sme mali $\mathrm{k}$ dispozícii výsledky pretestu a výsledky posttestu experimentálnej skupiny ESA (26 študentov), experimentálnej skupiny ESB (24 
študentov) a kontrolnej skupiny KS (23 študentov).

U každého študenta bola pri jednotlivých položkách administrovaného dotazníka $\mathrm{v}$ rámci pretestu ako aj v rámci posttestu ( 1 - Fyzika je mojím... hodnotenie obl'úbenosti predmetu; 2 Fyziku považujem za predmet... hodnotenie zaujímavosti predmetu; 3 - Fyzika patrí medzi predmety... hodnotenie náročnosti predmetu; 4 Výkladu nového učiva pri vyučovaní predmetu fyzika... hodnotenie zrozumitel'nosti výkladu; 5 - Vyučovaci predmet fyzika patrí medzi tie vyučovacie predmety, ktoré ako súčast vzdelania človeka považujete za... hodnotenie významu nadobúdaných poznatkov) zaznamenaná hodnota škály podl'a toho, akú mieru pozitívneho alebo negatívneho hodnotenia pri nej vyznačil. V položke 6 (Študenti sa učia jednotlivé vyučovacie predmety $z$ rôznych dôvodov. Z akého dôvodu sa väčšinou Vy učite fyziku?), 7 (Rôznym študentom vyhovujú rôzne spôsoby výkladu nového učiva. Aký spôsob výkladu vyhovuje najviac Vám? ) a 8 (Niektorí študenti mávajú pred vyučovacimi hodinami strach a trému. Čo vyvoláva u Vás strach pred hodinou fyziky?) vyberali študenti z ponúknutých alternatív jednu možnost', ktorá najlepšie vystihovala ich stanovisko. Zvyšné tri položky boli otázky otvoreného charakteru.

\section{Analýza dát pretestu}

Na základe výsledkov popisnej štatistiky sme stanovili nasledujúce nulové štatistické hypotézy:

1. H0: Odpoved' na položku 1PRE nezávisí od faktoru SKUPINA.

2. H0: Odpoved' na položku 2PRE nezávisí od faktoru SKUPINA.

3. H0: Odpoved' na položku 3PRE nezávisí od faktoru SKUPINA.

4. H0: Odpoved' na položku 4PRE nezávisí od faktoru SKUPINA.

5. H0: Odpoved' na položku 5PRE nezávisí od faktoru SKUPINA.

6. H0: Odpoved' na položku 6PRE nezávisí od faktoru SKUPINA.

7. H0: Odpoved' na položku 7PRE nezávisí od faktoru SKUPINA.

8. H0: Odpoved' na položku 8PRE nezávisí od faktoru SKUPINA.
Nezamietnutím stanovených štatistických nulových hypotéz pre položky pretestu sme preukázali rovnocennost' jednotlivých skupín vytvorených $\mathrm{v}$ rámci pedagogického experimentu. Na základe výsledkov analýzy dát pretestu bolo možné konštatovat', že všetky tri skupiny študentov (experimentálna skupina $A$, experimentálna skupina $\mathrm{B}$, kontrolná skupina KS) sú rovnocenné pre možnost' ovplyvňovania vzt'ahu a postojov študentov $\mathrm{k}$ vyučovaciemu predmetu fyzika prostredníctvom pedagogickej intervencie nami vytvorených elektronických učebných materiálov Základy geometrickej optiky. Z uvedeného následne vyplýva, že diferenciácia skupín $\mathrm{z}$ hladiska ich študijného zamerania a diferenciácia skupín $\mathrm{z}$ hl'adiska príslušnosti ku gymnáziu so štvorročným alebo osemročným štúdiom nie je opodstatnená.

\section{Analýza dát posttestu}

$\mathrm{Na}$ základe výsledkov popisnej štatistiky sme stanovili nasledujúce nulové štatistické hypotézy:

1. H0: Odpoved' na položku 1POST nezávisí od faktoru SKUPINA.

2. H0: Odpoved' na položku 2POST nezávisí od faktoru SKUPINA.

3. H0: Odpoved' na položku 3POST nezávisí od faktoru SKUPINA.

4. H0: Odpoved' na položku 4POST nezávisí od faktoru SKUPINA.

5. H0: Odpoved' na položku 5POST nezávisí od faktoru SKUPINA.

Vychádzajúc $\quad \mathrm{z}$ výsledkov KruskalWallisovho a mediánového testu bolo všetkých pät' nulových hypotéz zamietnutých. Potvrdilo sa teda, že závislé premenné 1POST až 5POST sú závislé na faktore SKUPINA, pričom štatisticky významný rozdiel bol v prípade položky 2POST len medzi skupinou ESA a skupinou ESB a v prípade ostatných položiek medzi skupinou ESA a oboma zvyšnými skupinami ESB a KS. Pre stručnost' uvádzame detailnejšie iba výsledky analýzy štvrtej položky posttestu (4POST). V prípade výsledkov analýzy zostávajúcich položiek posttestu sa obmedzujeme len na kvalitatívne zhodnotenie.

H0: Odpoved' na položku 4POST nezávisí od faktoru SKUPINA. 


\begin{tabular}{|l|c|c|}
\hline & Počet platných & Súčet poradí \\
\hline ESA (OKB) & 26 & 1380,000 \\
\hline ESB (OKA) & 24 & 794,000 \\
\hline KS (4.C) & 23 & 527,000 \\
\hline
\end{tabular}

Tabul'ka 3: Kruskal-Wallisov test pre položku 4POST.

Na základe výsledkov Kruskal-Wallisovho testu: $\mathrm{H}(2, \mathrm{~N}=73)=29,62133, \mathrm{p}=0,0000$ zamietame nulovú hypotézu $(\mathrm{p}<0,05)$ tvrdiacu, že rozdiel v hodnotení štvrtej položky posttestu medzi skupinami nie je štatisticky významný, takže závislá premenná 4POST je závislá na faktore SKUPINA.

\begin{tabular}{|l|c|c|c|c|}
\hline & ESA (OKB) & ESB (OKA) & KS (4.C) & Celkom \\
\hline <= Medián: pozorov. & 8,00000 & 20,00000 & 22,00000 & 50,00000 \\
\hline očakáv. & 17,80822 & 16,43836 & 15,75342 & \\
\hline poz. - oč. & $-9,80822$ & 3,56164 & 6,24658 & \\
\hline Medián: pozorov. & 18,00000 & 4,00000 & 1,00000 & 23,00000 \\
\hline očakáv. & 8,19178 & 7,56164 & 7,24658 & \\
\hline poz. - oč. & 9,80822 & $-3,56164$ & $-6,24658$ & \\
\hline Celkom: očak. & 26,00000 & 24,00000 & 23,00000 & 73,00000 \\
\hline
\end{tabular}

Tabul'ka 4: Mediánový test pre položku 4POST.

Výsledky mediánového testu: chí-kvadrát $=$ 27,45644 , df $=2, p=0,0000$, nám potvrdili výsledky Kruskal-Wallisovho testu $(\mathrm{p}<0,05)$.

Po zamietnutí hypotézy H0 sme si položili otázku:
Medzi ktorými skupinami je štatisticky významný rozdiel?

Výsledky viacnásobného porovnávania sú uvedené v tabul'ke 5.

\begin{tabular}{|l|c|c|c|}
\hline & ESA (OKB) R:53,077 & $\begin{array}{c}\text { ESB (OKA) } \\
\mathbf{R : 3 3 , 0 8 3}\end{array}$ & KS (4.C) R:22,913 \\
\hline ESA (OKB) & & 0,002615 & 0,000002 \\
\hline ESB (OKA) & 0,002615 & & 0,301314 \\
\hline KS (4.C) & 0,000002 & 0,301314 & \\
\hline
\end{tabular}

Tabul'ka 5: Viacnásobné porovnávanie pre položku 4POST.

Štatisticky významné rozdiely sú medzi prvou experimentálnou skupinou (ESA) a zvyšnými dvoma skupinami (ESB, KS) $(\mathrm{p}<$ $0,05)$. Výsledky viacnásobného porovnávania pre štvrtú položku posttestu nám vizualizuje krabicový graf 1.

Odpovede respondentov

prvej experimentálnej skupiny na štvrtú položku posttestu (Výkladu nového učiva pri vyučovaní predmetu fyzika...) boli ovplyvnené vzhliadnutím vytvorených elektronických učebných materiálov Základy geometrickej optiky a interaktívnej elektronickej učebnej pomôcky v podobe animovaných (flash) prezentácií a vzt’ahom, ktorý si k nim vytvorili. Vzdelávacia činnost' študentov $v$ druhej experimentálnej skupine bola realizovaná taktiež $\mathrm{s}$ vizuálnou podporou, $\mathrm{v}$ tomto prípade $\mathrm{v}$ podobe multimediálneho vzdelávacieho titulu Výukové prezentácie pre podporu vyučovania fyziky (autor: Jozef Beňuška) dodaného na kompaktnom disku bez možnosti využívania tohto titulu pri ich samoštúdiu $\mathrm{v}$ domácich podmienkach. 


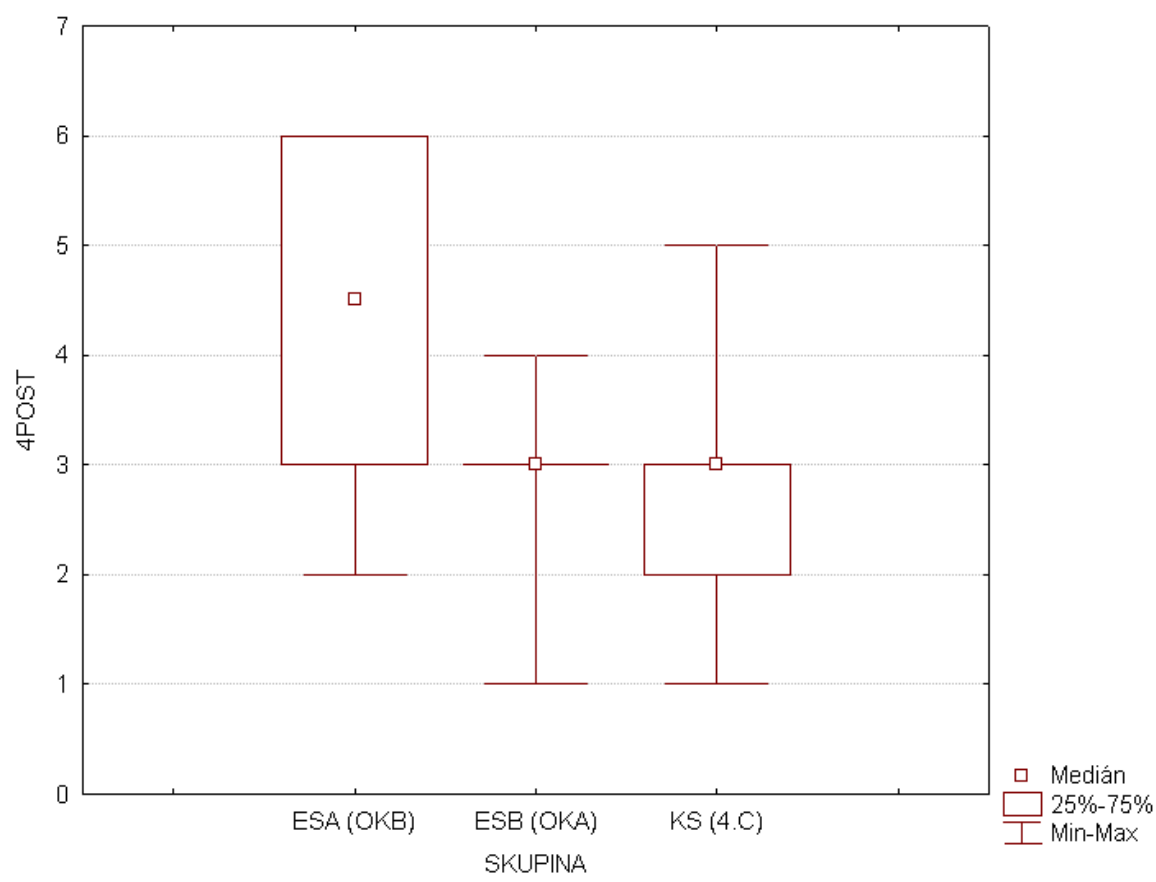

Graf 1: Krabicový graf štvrtej položky posttestu.

Z grafu 1 vidíme, že medián škály pre prvú experimentálnu skupinu (ESA) predstavuje hodnota 4,5. V druhej experimentálnej skupine (ESB) a kontrolnej skupine (KS) je hodnota mediánu škály 3 . Stredných $50 \%$ hodnôt odpovedí študentov pre prvú experimentálnu skupinu (ESA) sa pohybuje v rozmedzí 6 až 3, pre druhú experimentálnu skupinu (ESB) je hodnota kvartilového rozpätia 0 a pre kontrolnú skupinu (KS) sa pohybuje v rozmedzí 3 až 2 $\mathrm{z}$ maximálnej hodnoty škály 5 .

Uvádzané výsledky potvrdzujú, že učitelia by pri výklade nového učiva, obzvlášt' vo vyučovaní fyziky, mali využívat' interaktívne multimediálne pomôcky so simuláciami a pohybom. Navyše pre prezentáciu fyzikálnych javov nesporným plusom multimédií je, že umožňujú podporit' atraktívnost' prezentácie týchto procesov širokou škálou dynamických prvkov, farieb a zvukových efektov. Nazdávame sa, že je vel'mi dôležité použit' tieto prostriedky aj v d'alších exaktných predmetoch a urobit' tak vedu a technológiu prít’ǎlivejšou a atraktívnejšou pre mladých l'udí.

Zamietnutím štatistických nulových hypotéz pre prvých pät' položiek posttestu sa nám potvrdila naša výskumná hypotéza:

Predpokladáme, že vyučovanie podporované elektronickými výučbovými prostriedkami prispieva $k$ znižovaniu negativnych postojov $k$ vyučovacím predmetom, konkrétne $k$ vyučovaciemu predmetu fyzika.
6. H0: Odpoved' na položku 6POST nezávisí od faktoru SKUPINA.

7. H0: Odpoved' na položku 7POST nezávisí od faktoru SKUPINA.

8. H0: Odpoved' na položku 8POST nezávisí od faktoru SKUPINA.

Pre stručnost' uvádzame iba výsledné zhodnotenie: $\mathrm{v}$ prípade výsledkov analýzy rozdielov v odpovediach medzi jednotlivými skupinami respondentov sa tieto preukázali iba v rámci ôsmej položky administrovaného dotazníka.

V položkách 9 (Napišste 2 - 3 veci, ktoré Vám pri vyučovani fyziky najviac vadia), 10 (Napište 2 - 3 veci, ktoré Vás na hodinách fyziky najviac bavia) a 11 (Predmet fyzika by ma bavil, keby) mali študenti všetkých troch skupín (ESA, ESB, KS) možnost' vyjadrit' svoj názor formou vol'nej odpovede. Ked’že sa jednalo o položky dotazníka, ktoré neboli do štatistického spracovania pedagogického experimentu zahrnuté, v d'alšej časti uvádzame len kvalitatívnu analýzu spracovaných výsledkov odpovedí spomínaných položiek.

Odpovede študentov na uvedené 3 otázky boli vel'mi rôznorodé. Badatel'ný rozdiel bol $\mathrm{v}$ odpovediach medzi skupinami s rôznym spôsobom realizácie vyučovacieho procesu, t.j. či vzdelávacia činnost' študentov v skupine bola realizovaná s vizuálnou multimediálnou podporou (ESA, ESB) alebo bez nej (KS). Študenti obidvoch experimentálnych skupín (ESA, ESB) sa v otázke číslo devät' (Napište 2 - 
3 veci, ktoré Vám pri vyučovani fyziky najviac vadia) vo väčšine prípadov zhodli na odpovediach, že v obsahovej náplni fyziky je vel’a teoretického učiva, sú tam nezaujímavé, na pochopenie t’ažké, či v niektorých prípadoch dokonca nudné témy, „zastaralé“ učebnice, málo praktických vecí, či rozsiahlost' niektorých tematických okruhov. Študenti si v mnohých prípadoch nevedia predstavit', ako ten-ktorý fyzikálny zákon $\mathrm{v}$ praxi naozaj funguje. Občas zastávajú i názor, že vel’a preberanej látky je zbytočnej. Študentom kontrolnej skupiny (KS) vo vyučovaní fyziky vadí nedostatok kvalitných učebných pomôcok, ktorými by im bola priblížená značná abstrakcia niektorých fyzikálnych javov a procesov, ale aj samotný strohý, pre nich nezáživný, výklad učiva.

Odpovede študentov na desiatu položku dotazníka (Napište 2 - 3 veci, ktoré Vás na hodinách fyziky najviac bavia) v prípade obidvoch experimentálnych skupín (ESA, ESB) vyjadrovali záujem o zavádzanie názorných animácií a interaktívnych simulácí́ preberaného učiva do edukačného procesu v škole ale aj do domácej prípravy. Potešitel'ný je aj značný záujem študentov o realizovanie laboratórnych cvičení a zaujímavých fyzikálnych pokusov. Pre ilustráciu uvádzame niektoré najfrekventovanejšie názory respondentov, ktoré sa pri rozbore výsledkov odpovedí spomínanej položky vyskytli: výklad učiva sprevádzaný počitačovými animáciami; vysvetlenie učiva pozeraním náučných filmov; diskusie opreberaných témach; zaujimavý výklad učiva profesorkou; laboratórne cvičenia; fyzikálne pokusy; rôzne projekty; využivanie dataprojektora a názorných učebných pomôcok.

V poslednej položke dotazníka (Predmet fyzika by ma bavil, keby) dostali študenti možnost' vyjadrit', so zmenou čoho by ich vyučovací predmet fyzika začal bavit' viac ako doteraz, čo by následne mohlo ovplyvnit' zmenu ich postoja a vzt'ahu $\mathrm{k}$ tomuto predmetu. Išlo o položku provokatívnu, pre mnohých respondentov možno neočakávanú. Po analýze odpovedí všetkých troch skupín (ESA, ESB, KS) môžeme skonštatovat', že najčastejšími boli pripomienky vznášané už v položke číslo devät'. Respondenti zlepšenie ich vzt'ahu $\mathrm{k}$ fyzike spájajú s preberaní učiva na menej teoretickej báze, s väčším zaoberaním sa praktickým využívaním nadobúdaných fyzikálnych poznatkov, s realizáciou väčšieho počtu laboratórnych cvičení a fyzikálnych pokusov, s častejším využívaním učebných pomôcok a so zaoberaním sa aplikáciami preberaného učiva $\mathrm{v}$ každodennom živote na praktických cvičeniach a príkladoch. Zároveň však vel'a študentov požadovalo, aby ich študijné výsledky dosiahnuté $\mathrm{v}$ tomto predmete neboli klasifikované známkou, resp. aby bol povinný len pre tých, ktorí majú záujem venovat' sa fyzike $\mathrm{v}$ budúcnosti.

\section{Záver}

Realizovaným pedagogickým experimentom sme overili hypotézu, že vyučovanie podporované elektronickými výučbovými prostriedkami prispieva k znižovaniu negatívnych postojov $\mathrm{k}$ vyučovacím predmetom, konkrétne k vyučovaciemu predmetu fyzika $\mathrm{v}$ danej vekovej kategórii študentov. Preukázali sme, že používanie nami vytvorených multimediálnych učebných materiálov Základy geometrickej optiky v rámci multimédiami podporovaného vyučovania malo pozitívny vplyv na hodnotenie položiek dotazníka posttestu. V prípade experimentálnej skupiny ESA, u ktorej vyučovací proces prebiehal $\mathrm{s}$ pedagogickou intervenciou týchto materiálov, došlo v postteste oproti zvyšným skupinám (experimentálnej skupine ESB a kontrolnej skupine KS) k pozitívnemu posunu v hodnotení oblúbenosti fyziky, zaujímavosti obsahu fyziky, náročnosti fyziky, zrozumitel'nosti výkladu a dokonca aj významu vo fyzike nadobúdaných poznatkov pre rozvoj a uplatnenie sa jednotlivca.

Vytvorené výučbové materiály Základy geometrickej optiky sú pritom využitel'né pre podporu vyučovania aj bez špeciálneho zamerania účelu ich využitia vo výchovno vzdelávacom procese. Hlavnú úlohu v nich hrá vizualizácia spracovaných fyzikálnych pojmov a zákonitostí vo vel'kom množstve (flash) animácií a interaktívnych simulácií optických javov. Materiály boli prezentované a konfrontované $\mathrm{v}$ rámci viacerých medzinárodných odborných konferencií a sút'aží doma i v zahraničí. Medzi ich najvýznamnejšie ocenenia možno zaradit' 1. miesto v kategórii Podporný materiál pre online vzdelávanie $\mathrm{v}$ medzinárodnej sútaži vzdelávacích projektov E-learning $v$ praxi, ktorá bola súčast'ou 5. ročníka medzinárodnej konferencie ICETA 2007 venovanej novým e-learningovým technológiám a ich aplikáciám 
usporiadanej Technickou univerzitou v Košiciach (Stará Lesná, 5. - 8. 9. 2007).

\section{Literatúra}

(1) HORÁKOVÁ, G. - MUCHA, V.: Kvalita vedomostí získaných výučbou podporovanou počítačom. Informatika v škole, 33/34, 2008, s. 40 - 42. ISSN 1335-616X.

(2) NAGY, T. - KUBIATKO, M. NAGYOVÁ, S. Postoje žiakov v spojitosti s prípravou učitel'ov $\mathrm{v}$ problematike implementácie IKT do vyučovacieho procesu. Informatika $v$ škole 33/34, 2008, s. 20 - 24. ISSN 1335-616X. URL : < http://www.uips.sk /sub/uips.sk/images/JE/cas_informatika/infor33 34\%202008.pdf >. [cit. 12/11/2008].

(3) POLČIN, D. Multimediálne prezentácie vo výučbe v školách. Informatika v škole, 29/2005, s. $5-8$.

(4) TALT, B. Constructive Internet based learning. URL : < http://www.ilt.ac.uk/ public/cti/ActiveLearning/al7pdf/tait.pdf $>$

(5) ZÁHOREC, J. Elektronické výučbové prostriedky $\quad \mathrm{v}$ technológii vzdelávania. Dizertačná práca. Nitra, PF UKF, 2008.

(6) ZÁHOREC, J. - HAŠKOVÁ, A. Assessment of the current state of Informatics and Programming teaching from the students' point of view : Hodnotenie stavu vyučovania informatiky a programovania z pohl'adu študentov. JTIE - Journal of Technology and Information Education, 2009, č. 1, s. 83 - 91. ISSN 1803-537X (print), ISSN 1803-6805 (online).

(7) ZÁHOREC, J. - HAŠKOVÁ, A. - MUNK, M. Research Results Aimed at Influencing Students`Attitudes Towards Physics Through Electronic Teaching Materials. Information \& Communication Technology in Natural Science Education. Siauliai (Lithuania), Siauliai University, Natural Science Education Research Centre, Faculty of Education, 2008. s. 143 149. ISBN 978-9986-38-943-9

\section{Prof. PaedDr. Alena Hašková, CSc.}

PaedDr. Ján Záhorec, PhD.

Ústav technológie vzdelávania

Pedagogická fakulta Univerzity Konštantína

Filozofa

Dražovská cesta 4

94974 Nitra, SK

E-mail: ahaskova@ukf.sk, jzahorec@ukf.sk www.ukf.sk 